\title{
Luminal Breast Cancer: Risk of Recurrence and Tumor-Associated Immune Suppression
}

\author{
Benedetta Pellegrino ${ }^{1,2}\left(\mathbb{D} \cdot\right.$ Zuzana Hlavata $^{3} \cdot$ Cristina Migali $\cdot$ Pushpamali De Silva ${ }^{5} \cdot$ Marco Aiello $^{6}$. \\ Karen Willard-Gallo ${ }^{7} \cdot$ Antonino Musolino $^{1,2} \cdot$ Cinzia Solinas $^{8}$
}

Accepted: 12 April 2021 / Published online: 11 May 2021

(c) The Author(s) 2021

\begin{abstract}
Hormone-receptor positive (HR+) breast cancer (BC) (including the luminal A and the luminal B subtypes) is the most common type of tumor in women diagnosed with early-stage BC (EBC). It represents a highly heterogeneous subgroup that is characterized by different risks of relapse. The aim of this review is to discuss the possible role played by the immune response in predicting this risk, along with the most common clinical and pathological factors and molecular tools that have been developed and are already in use. As opposed to what has previously been observed in the most aggressive human epidermal growth factor receptor 2 (HER2)-positive and triple-negative breast cancer (TNBC) subtypes, a high proportion of tumor-infiltrating lymphocytes (TILs)—reflecting a spontaneous and pre-existing immune response to the tumor-has been linked to a worse prognosis in HR+EBC. This work provides some immune biological rationale explaining these findings and provides the basics to understand the principal clinical trials that are testing immunotherapy in HR+ (luminal) BC.
\end{abstract}

\section{Introduction}

Breast cancer $(\mathrm{BC})$ is the second leading cause of cancer death in women (with about 143,000 deaths per year in Europe) [1], and with over 2 million new cases worldwide in 2018, it is the most common tumor in women [2]. BC patients with a known stage are usually diagnosed early

Antonino Musolino and Cinzia Solinas contributed equally to this work.

Benedetta Pellegrino

benedetta.pellegrino@unipr.it

Zuzana Hlavata

zuza.hlavata@gmail.com

Cristina Migali

cristina.migali@yahoo.it

Pushpamali De Silva

pushpamali.de.silva@gmail.com

Karen Willard-Gallo

karen.willard-gallo@bordet.be

Cinzia Solinas

czsolinas@gmail.com

1 Department of Medicine and Surgery, University of Parma, Str. dell'Università, 12, 43121 Parma, PR, Italy

2 Medical Oncology and Breast Unit, University Hospital of Parma, Parma, Italy

\section{Key Points}

In luminal/HER2-negative tumors, a high proportion of tumor-infiltrating lymphocytes was a negative prognostic factor.

Several trials are currently testing the efficacy of immune checkpoint blockade in hormone-receptor positive breast cancer, and it is hoped that the results will confirm the potential therapeutic role of immunomodulation in this subgroup of patients.

3 Department of Medical Oncology, CHR Mons-Hainaut, Avenue Baudouin de Constantinople, n. 5, Mons, Hainaut, Belgium

4 Italian Medicines Agency (AIFA), Rome, Italy

5 Wellman Center for Photomedicine, Department of Dermatology, Harvard Medical School and Massachusetts General Hospital, Boston, MA, USA

6 Medical Oncology Unit, Azienda Ospedaliero-Universitaria Policlinico San Marco, Catania, Italy

7 Molecular Immunology Unit, Institut Jules Bordet, Bruxelles, Belgium

8 Azienda Tutela della Salute Sardegna, Ospedale A. Segni, Ozieri, Italy 
in $79-87 \%$ of cases (stage I or II), with $13-21 \%$ of diagnoses made at a late stage (stage III or IV). Up to $7 \%$ of BC patients have metastases at diagnosis (stage IV) [3-5]. Despite early diagnoses, particularly after the introduction of the mammographic screening and surgery that allows a cure of most cases of early-stage BC (particularly luminal tumors), recurrence still occurs.

Therefore, adjuvant treatments (i.e., radiotherapy (RT), chemotherapy (CT), hormone therapy (HT), and anti-human epidermal growth factor receptor 2 (HER2)-targeted therapies), aiming to eradicate early systemic dissemination of microscopic disease, are commonly used to reduce the risk of relapse. Despite this progress, about $15 \%$ of patients will present a loco-regional relapse (i.e., tumor localized in breast and/or regional lymph nodes (LNs)) in the following 5 years [6]. Seventy-eight percent of women are predicted to survive for 10 years or more, as shown by age-standardized net survival for patients diagnosed with BC during 2010-2011 in England and Wales (Cancer Research UK Cancer Survival Group, London School of Hygiene and Tropical Medicine. Personal communication, 2014) and 10-year overall survival (OS) is about $86 \%$ and $78 \%$, respectively [7].

A variety of clinical, pathological and molecular tools are used nowadays for treatment decisions in the adjuvant setting in luminal BC (e.g., whether CT administration is appropriate or not, based on the risk of relapse). In addition, novel biomarkers are under evaluation. Among them, a high proportion of tumor-infiltrating lymphocytes (TILs), as assessed on hematoxylin and eosin (H\&E)-stained slides, in luminal primary $\mathrm{BC}$ was associated with a worse outcome, this is different from what was observed in the most infiltrated and aggressive BC subtypes (HER2-positive (HER2+) and triple negative $\mathrm{BC}$ (TNBC)), where high TILs predicted a better prognosis [8]. Thus, it could be speculated that, as opposed to HER2+ and TNBC, an efficient immune escape might represent one of the factors influencing recurrence in hormone receptor (HR)+ (= luminal) EBC.

Further, cancer immunotherapy through immune checkpoint blockade (ICB) has recently gained some success particularly in the treatment of TNBC patients in the metastatic and neoadjuvant settings $[9,10]$. By incorporating immunotherapy into the standard TNBC treatment the revolution has been initiated, bringing new challenges, such as the assessment of responses to treatments with different timings and heterogeneous patterns of toxicity in a variety of organs [11-15], as well as the biggest issues of patient selection and the identification of ideal combinational drugs that might enhance the efficacy of ICB [9, 16-20]. In this light, luminal BC still remains an orphan with regard to immunotherapy options. It is becoming clearer that the heterogeneity of the various BC subtypes (luminal vs. HER2+ vs. TNBC) possibly explains the marked diversity of the spontaneous immune-related mechanisms that are generated, making it likely that their manipulation through ICB or other strategies (i.e., vaccines) will vary depending on the subtype [21, 22].

The aim of this review was to investigate the prognostic and predictive roles of the tumor immune environment, particularly with regard to the adaptive immunity in HR+ EBC patients.

\section{Prognostic and Predictive Factors in Early-Stage Breast Cancer (BC)}

\subsection{Prognostic Factors}

There are several strong prognostic factors for recurrence in EBC: tumor size $(=\mathrm{T})$ [23], $\mathrm{LN}$ involvement $(=\mathrm{N})$ [24], histological tumor grade [25], and the degree of tumor proliferation (= Ki67) [26]. There is also strong evidence for specific clinical and pathological factors, such as in the case of inflammatory BC, which is associated with a worse outcome [27], whereas tubular and mucinous carcinomas have a better prognosis [28]. HR status is both a prognostic and a predictive factor in EBC [29,30]. While positivity of HR is associated with better prognosis, tumors with an overexpression of HER2/neu, which are found in 16-19\% of cases, have a significantly worse prognosis (i.e., disease-free survival (DFS) and OS) [31].

Moreover, in 2000 Perou et al. proposed the "molecular profiling in BC, " categorizing tumors into four molecular subtypes: (1) luminal A (=ER+ and/or PR+ and HER2 - and low level of Ki67), (2) luminal B (ER+ and/ or PR+ and/or HER2+ and high level of Ki67), (3) HER2enriched (ER - and PR-/HER2+), and (4) basal-like (ER- and PR- and HER2-) [32]. Based on the assessment of these molecular subtypes through gene-expression profiling, we might more precisely assess prognosis and improve the prediction of benefit from CT in luminal subtypes. Indeed, different median durations of survival with distant metastases were shown in Luminal A ( $=2.2$ years), Luminal B $(=1.6$ years $)$, Luminal/HER2 $+(=1.3$ years $)$, HER2 enriched $(=0.7$ years $)$, and basal-like $(=0.5$ years $)$ [33]. However, recent data from trials on cyclin-dependent kinases (CDK) 4/6 inhibitors administered in metastatic luminal $\mathrm{BC}$ reveal that OS could be superior, up to 3 years, in this group of patients [34, 35]. In addition, distinct patterns of metastatic spread within the different BC subtypes were observed. With the only exception being in the basallike subtype, bone was the most common site of metastases. A higher rate of brain, lung, and LN metastases was specifically observed in basal-like tumors [33].

So far, a variety of gene-expression-profiling methods, such as Oncotype DX [36], MammaPrint [37], PAM50 [38], Breast Cancer Index [39], PREDICT score [40, 41], IHC4score [42, 43], Clinical Treatment Score (CTS) [44], Magee 
equation [45], and EndoPredict [46] have been developed to increase the accuracy on the prediction of the risk of recurrence, in order to guide treatment decisions (mainly adjuvant CT vs. no) in luminal subtypes. Unfortunately, none of these tests are currently used in clinical practice. A genomic signature provides stratification for early versus late recurrences in $\mathrm{HR}+\mathrm{EBC}$. However, it has been internally but not externally validated [47]. Usually, in HR+ HER2- tumors (luminal A and B), systemic adjuvant therapy is based on HT, which is different between pre- and post-menopausal women. While the luminal A subtype is usually associated with a very good prognosis and the systemic adjuvant therapy is most likely HT alone, luminal B HER2- tumors can benefit from adjuvant $\mathrm{CT}$. Indeed, the decision on what type of adjuvant treatment should be used in order to avoid over- or undertreatment in clinical practice remains very challenging. For instance, the phase III prospective randomized clinical trial "Microarray In Node-negative Disease may Avoid Chemotherapy" (MINDACT) aimed to dissect the issue of omission of adjuvant CT in patients with "discordant features," which means having high clinical (based on the traditional clinicopathological criteria, i.e., T, grade, presence or absence of HR, LN involvement) but low genetic risk of recurrence (evaluated with the MammaPrint signature). The absolute benefit from adding $\mathrm{CT}$ in this selected patient population was less than $2 \%$ in 5-y OS (98.8\% vs. $97.0 \%)$, and less than 5\% in 5-y DFS (93.3\% vs. 88.8\%), although the trial was not powered for such comparisons [48]. Furthermore, in the HR+ population, despite-or perhaps "due to"-having very good prognosis, late relapses (i.e., taking place $>5$ years after diagnosis) still occur depending on risk factors mentioned above, as well as on the "impact of treatment" [49]. Despite all these efforts, adjuvant CT is not able to reduce late recurrences in $\mathrm{HR}+\mathrm{EBC}$. As a consequence, several randomized trials were performed to evaluate the benefit from extended adjuvant HT and justify its use in certain conditions [50-53]. However, the real benefit remains small, if any, and it is further reduced by the occurrence of adverse events [54]. Therefore, we return to the question of (1) how to identify patients with a high risk of late recurrence, and (2) how to treat them.

Ethier et al. conducted a systematic review with metaanalysis regarding the prognostic role of neutrophil-tolymphocyte ratio (NLR) in breast cancer [55]. Fifteen studies comprising a total of 8,563 patients were included [55]. Higher NLR was associated with worse OS (HR 2.56, 95\% CI 1.96-3.35; $p<0.001)$ and DFS (HR 1.74, 95\% CI $1.47-2.07 ; p<0.001$ ) [55]. This association was similar in studies including only early-stage disease and those comprising patients with both early-stage and metastatic disease. NLR had greater prognostic value for DFS in HR- and HER2- breast cancer, but no subgroup showed an influence on the association between NLR and OS.
The tumor cell dormancy phenomenon could explain the capability of disseminated tumor cells (DTCs) that give rise to metastases. These cells create non-proliferating dormant micro metastases for long periods of time, through immune escape or switch to angiogenesis [56]. Kim et al. performed a 49-gene signature specific for the analysis of tumor-cell dormancy (gene profiles including tumor cell quiescence and angiogenic regulation) in both BC cell lines and primary $\mathrm{BC}$ tumors, with the aim of finding the correlation between the dormancy gene profile and BC outcome. They defined the dormancy score by considering upregulated as positive genes and downregulated as negative genes in dormant cells. Among HR+ tumors, a higher dormancy score was significantly associated with a lower hazard of metastasis. Remarkably, a correlation between the dormancy score and the survival in HR+ tumors was observed. This was not the case for HR- tumors. Additionally, by comparing the dormancy scores of luminal A versus luminal B tumors, it was shown that the median score was significantly lower in the luminal B compared to the luminal A tumors [57].

\subsection{Predictive Factors}

So far, only three validated predictive factors of benefit from standard (neo)-adjuvant treatments exist in EBC: (1) estrogen receptor (ER), (2) progesterone receptor (PgR), and (3) HER2 (over)-expression. These factors are routinely used for the selection of patients for HT (with the presence of ER+ and/or PgR+ tumors) and anti-HER2 therapies (in HER2 overexpressing tumors), respectively. The TAILORx trial demonstrated the negative predictive role to chemotherapy in early HR+ breast cancer for tumor with a recurrence score lower than 25 [58]. In any case, its application is still limited in clinical practice in European Countries.

\section{The Tumor Microenvironment in Luminal BC}

The tumor microenvironment (TME) includes a variety of non-immune and immune cells producing many factors that can drive a chronic inflammatory, differently balanced situation: either a pro- and an anti-tumor or pro-angiogenic tumor environment [59] (Fig. 1). Among the non-immune cells, the stromal components of the TME consist of cancerassociated fibroblasts (CAFs), endothelial cells, and pericytes. Immune cells are particularly abundant in the stroma and less numerous in intra-tumoral areas [59]. They are composed of macrophages [tumor-associated macrophages (TAMs)], dendritic cells (DCs), myeloid-derived suppressor cells (MDSC), natural killer (NKs) cells, mast cells (MCs), granulocytes, plus the cells of the adaptive immunity, B and $\mathrm{T}$ lymphocytes. Naïve $\mathrm{T}$ cells represent the minority, while 
memory $\mathrm{T}$ cells are the majority of cells, including cytotoxic $\mathrm{CD}^{+} \mathrm{T}$ cells (CTL) and different subsets of $\mathrm{CD} 4^{+} \mathrm{T}$ helper (Th) and immunosuppressive regulatory T cells (Tregs) [60]. It is noteworthy that $\mathrm{B}$ and $\mathrm{T}$ lymphocytes can be organized in tertiary lymphoid structures (TLS) whose role in BC has not been clearly defined yet $[61,62]$. One can speculate that, potentially, all of these cells could have different impacts at different times and/or phases of tumor progression to control the (pro- or anti-) balance of the TME.

Immune cells can have pro-tumor or anti-tumor activity depending on how they communicate with tumor cells and with the other immune cells via the "inflammatory crosstalk network." It is evident that the BC-TME is different within the various subtypes, due to their marked heterogeneity. Furthermore, luminal BC was classified into three subgroups, beyond Luminal A and Luminal B subtypes, using the expression of 130 immune-related genes: high-TIL, low-TIL, and high-Interferon Stimulated Genes (ISG) [63]. Thus, we can observe different clinical patterns, prognostic characteristics, and biologic behaviors [63].
The role of TME components in modulating the response to anti-estrogen therapy in $\mathrm{HR}+\mathrm{BC}$ has not been fully clarified. However, pre-clinical data validated several cytokines that drive resistance to HT (i.e., Fibroblast Growth Factor 2 (FGF2) and Neuregulin 1 (NRG1)) [64].

\subsection{Clinical Significance of Tumor-Infiltrating Lymphocytes in HR+ BC}

A standardized methodology for evaluating TILs is a prerequisite for integrating this parameter in standard histopathological practice, in a research setting as well as in clinical trials [59]. This approach was established by Salgado et al. in 2015 and recommends reporting TILs as the stromal compartment ( $=\%$ stromal TILs) [59]. The denominator used to determine the $\%$ stromal TILs is the area of stromal tissue (i.e., area occupied by mononuclear inflammatory cells over total intratumoral and stromal area), not the number of stromal cells (i.e., fraction of total stromal nuclei that represents mononuclear inflammatory cell nuclei) [59].

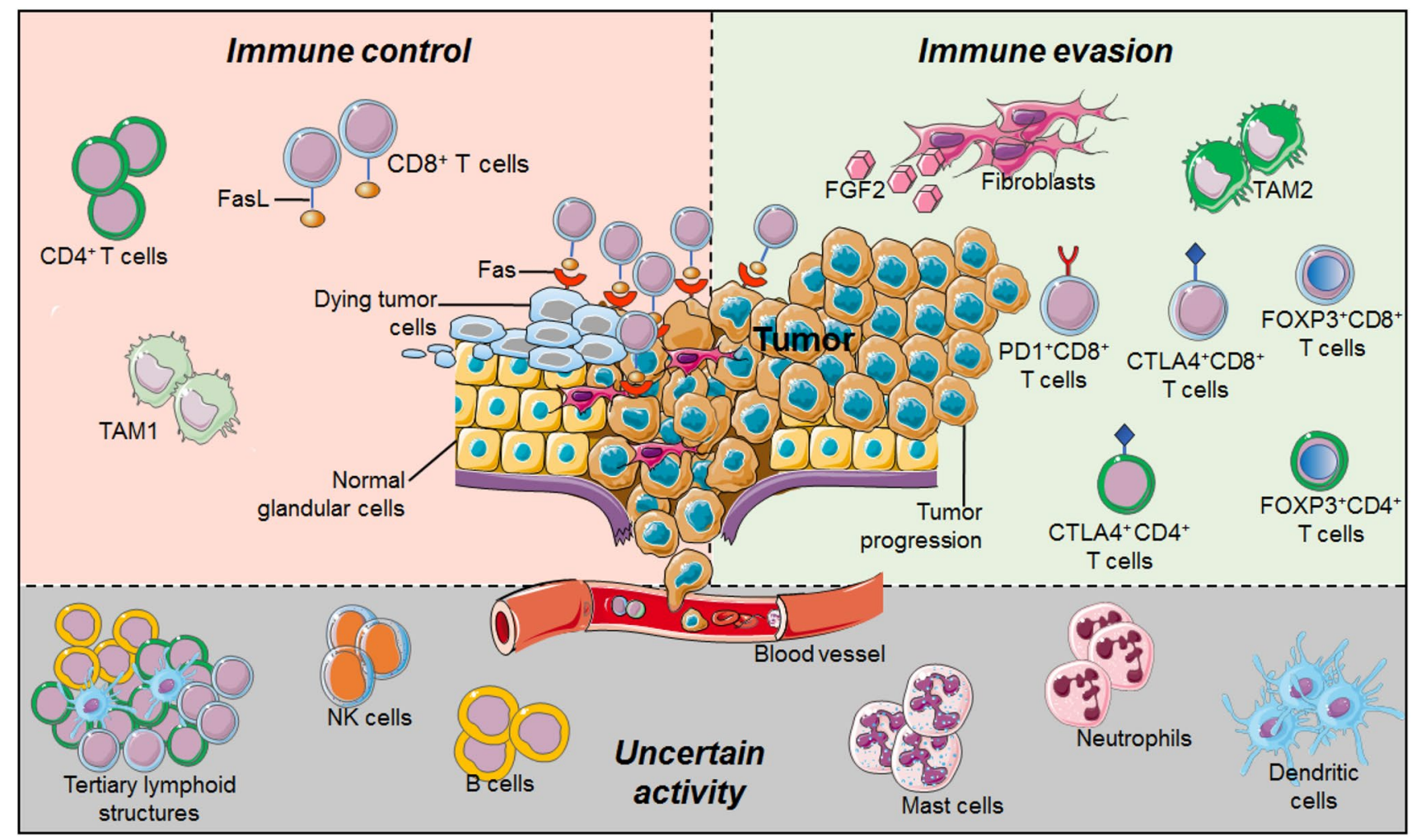

Fig. 1 The role of tumor microenvironment in hormone receptorpositive breast cancer. The tumor microenvironment of luminal breast cancer includes a variety of non-immune and immune cells producing many factors that can drive a chronic inflammatory, differently balanced situation: either a pro- and an anti-tumor or pro-angiogenic tumor microenvironment. TAM-1 tumor-associated macrophages type 1, TAM-2 tumor-associated macrophages type 2, FGF2 fibroblast growth factor 2, Fas- $L$ Fas ligand, Fas Fas receptor 
Recently, Criscitiello et al. evaluated the extent of TILs in a retrospective mono-institutional case-cohort series of 987 patients with early ER+/HER2- BC [65]. In multivariable regression analysis, TILs correlate with higher Ki67 expression; at univariate Cox regression analysis, TIL level ( $\geq 5 \%$ vs. $<5 \%$ ) was not associated with distant DFS (DDFS) $(p=0.62)$ [65]. Indeed, high TILs $(\geq 5 \%)$ were associated with better DDFS only in patients treated with adjuvant chemotherapy ( $p=0.006)$ [65].

Moreover, Denkert et al. showed that the presence of TILs assessed on H\&E-stained slides is an independent predictor of response to neoadjuvant $\mathrm{CT}$ in all subtypes, particularly in TNBC and HER2-positive BC [66]. They further analyzed the association between the amount of TIL and the longterm outcomes (event-free survival and OS) in 2,560 patients with EBC undergoing neoadjuvant therapy. While increased TILs were associated with a survival benefit in HER2-positive and TNBC, in luminal/HER2-negative tumors high TIL was a negative prognostic factor, raising the question of the role played by the immune system in these tumors. Similar results were reached by Gao et al. and Waks et al., analyzing the association between pCR and survival, and TILs in $\mathrm{HR}+\mathrm{BC}[67,68]$. Further, another issue is how achieving a pathological complete response (pCR) correlates with long-term outcome in HR+ HER2-negative BC. Indeed, a recent meta-analysis by Spring et al. showed that patients with $\mathrm{HR}+\mathrm{BC}$ with pCR had only a trend towards a lower risk for recurrence versus patients without pCR [69]. A significant positive correlation was found between $\mathrm{pCR}$ and long-term outcomes for high-grade HR+ tumors only [69].

A meta-analysis of 25 studies comprising 22,964 patients showed that TILs improve OS in TNBC (HR 0.82; 95\% CI 0.76-0.88 for DFS; HR 0.79; 95\% CI $0.71-0.87$ for OS) and HER2+ patients (HR 0.90; 95\% CI 0.82-0.99 for DFS), but not in estrogen-receptor positive $(\mathrm{ER}+)$ patients (HR 1.01; 95\% CI 0.94-1.07 for DFS; HR 1.09; 95\% CI 0.98-1.21 for OS) [70].

Mahmoud et al. explored the prognostic value of tumorinfiltrating CTL in unselected BC patients with long-term follow-up [71]. They found a positive correlation between the total number of $\mathrm{CD}^{+}$cells (= density) and higher grade, and a negative correlation with a patient's age at diagnosis, ER and PgR expression [71]. In HR- and basal phenotype tumors, remarkably the total $\mathrm{CD}^{+}$counts were associated with better BC-specific survival, although in $\mathrm{HR}+$ tumors the total number of infiltrating $\mathrm{CD}^{+}$cells was not significantly associated with patient outcome [71].

\subsection{FOXP Family and the Immune Response to BC}

Preclinical studies showed that forkhead box P3 (FOXP3 $\left.{ }^{+}\right)$ regulatory $\mathrm{T}$ cells (Tregs) can inhibit the anti-tumor immune response [72]. In BC, tumor-infiltrating FOXP3 ${ }^{+}$Tregs play a crucial role in immune escape [73, 74]. However, their prognostic value remains unclear. Mahmoud et al. analyzed the density of FOXP3 ${ }^{+}$cells in a series of 1,445 cases of well-characterized primary invasive $\mathrm{BC}$ cases with longterm follow-up. The total number of FOXP3 ${ }^{+}$cells showed a significant negative correlation with higher grade and HR. In addition, FOXP3 infiltration positively correlated with HER2 expression and the basal phenotype. The presence of intra-tumoral $\mathrm{FOXP}^{+}$cells was associated with a worse prognosis on univariate analysis, but no significant prognostic role was found in multivariate analysis [75]. The meta-analysis performed in $\mathrm{HR}+\mathrm{BC}$ revealed lower OS in patients with high versus low tumor-infiltrating FOXP3 ${ }^{+} \mathrm{T}$ cells but not in the HR- population [76]. Further, Liu et al. confirmed that the presence of high levels of FOXP3 ${ }^{+}$TIL is associated with young age, high grade, HR negativity, concurrent $\mathrm{CD}^{+}$TIL infiltration, HER2 positivity, and core basal subtypes. However, in $\mathrm{HR}+\mathrm{BC}$ lacking $\mathrm{CD}^{+} \mathrm{T}$-cell infiltrates, a high level of FOXP3 ${ }^{+}$TIL was significantly associated with a poor survival [77]. This might signify that the balance between different subsets of immune cells can have a different impact on prognosis according to the various BC subtypes. Previously, Bates et al. showed that by quantification of $\mathrm{FOXP}^{+}$Tregs we could identify patients at risk of late relapse within the $\mathrm{HR}+$ subgroup [78].

An emerging member of the FOXP subfamily, FOXP1 (similar to the well-known FOXP3 whose role in regulatory T cells has been extensively studied [79]) is abnormally expressed in diverse human tumors including BC [80]. The FOXPl gene is located in a tumor suppressor locus at $3 \mathrm{p} 14.1$ and the loss of its expression in BC (as well as in endometrial, prostate, and renal cell carcinomas) has been associated with a worse outcome [81, 82].

In the immune system, information on FOXP1 is currently limited but rapidly growing, with studies showing that it functions as an essential transcriptional regulator of B cell lymphopoiesis [82] and plays a critical role in monocyte differentiation and macrophage function [83, 84]. In murine models, conditional deletion of the FOXPl gene in $\mathrm{CD}^{+}$ $\mathrm{CD}^{+}$thymocytes revealed it is also essential for the generation of quiescent naïve T cells $[85,86]$.

This is also further elaborated by the work of Garaud et al., demonstrating the key role of FOXP1 in human peripheral blood $\mathrm{CD}^{+}{ }^{+} \mathrm{T}$-cell quiescence and T-helper $(\mathrm{Th})$ cell differentiation [87]. Further, Shi et al. found that FOXP1 upregulates the expression levels of cytotoxic T lymphocyte antigen -4 (CTLA-4) in conventional CD $4^{+} \mathrm{T}$ cells abrogating their differentiation into follicular helper $\mathrm{T}$ cells in vivo [88]. With regard to FOXP1 expression in $\mathrm{CD}^{+} \mathrm{T}$ cells, a study demonstrated that upregulation of FOXP1 in breast tumor-derived $\mathrm{CD}^{+} \mathrm{T}$ cells drives $\mathrm{T}$-cell unresponsiveness by blocking proliferation and major T-cell functions, including degranulation of cytotoxic granules and cytokine release. 
This state, which is distinct from anergy and exhaustion, involves FOXP1 and Smad2/Smad3 interactions, both translocated to the nucleus in response to transforming growth factor-beta (TGF $\beta$ ) signaling [89]. Moreover, a recent study showed that FOXP1 serves an essential function in Tregs to maintain their suppressive action by enforcing FOXP3mediated regulation of gene expression [90].

FOXP1 is normally expressed by normal breast tissues and its expression is dysregulated in breast tumor epithelial cells [91]. Stromal cells also express FOXP1; these include fibroblasts, inflammatory cells, and endothelial and pericyte lining vessels. Over the past decades, several studies have demonstrated the significance of FOXP1 expression in BC and its link to prognosis since its discovery in 2001 [81]. FOXP1 may partly be regulated by ER expression, and it was shown previously that increased FOXP1 expression had a significant positive association with ER expression in primary human BC [91]. This correlation was further investigated to seek the transcriptional regulation of FOXP1 by ER in the ER+ MCF7 BC cell line where it was found that estrogen stimulation could significantly upregulate FOXP1 within a short time period [92]. Apart from ER regulation, a study demonstrated that it may be regulated via the PI3K/Akt/ p70S6K signaling pathway [93]. Few studies showed that FOXP1 expression has been associated with better prognosis exploring in ER+ BC [91, 92, 94]. There is also information on breast cancer gene (BRCA) status and FOXP1, where negativity for FOXP1 was associated with a significantly worse OS in BRCA2 cancers [94]. However, recent reports suggest FOXPl as an oncogene in ER- BC [93, 95].

\subsection{CTLA-4: A Key Actor in Cancer Immune Evasion}

CTLA-4 is predominantly expressed in FOXP3 ${ }^{+}$Tregs or activated conventional T cells [96]. Expression of CTLA-4 was also described on $\mathrm{CD}^{+}$Tregs [97] that are able to suppress the anti-tumor immune response by inhibiting the proliferation of effector $\mathrm{T}$ lymphocytes (participating in the regulatory mechanisms of interleukin (IL)-35) [98] and by inhibiting dependent allogenic responses [99].

Preclinical research on mice models injected with poorly immunogenic metastatic mouse mammary carcinoma 4T1 cells was performed to test the hypothesis of the efficacy of radiotherapy (RT) in primary tumor with CTLA-4 ICB. It was shown that RT alone blocked the progression of the primary tumor but in the absence of the anti-CTLA-4 monoclonal antibody (mAb) there was no benefit in survival. Indeed, CTLA-4 mAb alone did not have any effect on the primary tumor growth or survival. However, mice treated by combined therapy had a statistically significant survival benefit [100]. These observations suggest the role of possible systemic effects of RT when given in association with ICB [101].
The role of CTLA-4 expression was investigated by Mao et al. in breast tissues. The immunohistochemical (IHC) staining and reverse transcriptase polymerase chain reaction (RT-PCR) were performed in $60 \mathrm{BC}$ patients and in 30 normal controls. The strong expression of CTLA-4 at both protein and mRNA levels was detected in tumor cells and a higher mRNA level of CTLA-4 was associated with worse LN involvement [102].

Further, in primary breast tumor tissues a significant hypomethylation of $\mathrm{CpG}$ islands in the promoter region of CTLA-4 compared with normal tissues was observed, signifying an upregulation of the CTLA-4 gene [103].

At the protein level, expression of CTLA-4 by IHC was found in both immune cells (at the cytoplasmic level) and tumor cells in around $50 \%$ of $\mathrm{BC}$ analyzed in a retrospective study including 93 tumors [104]. Interestingly, another retrospective study analyzed the clinical impact of the expression of CTLA-4 by different cells of the TME in BC showing that the group of patients with high CTLA-4 expression on interstitial lymphocytes and with a low CTLA-4 expression on tumor cells had the best outcomes (DFS and OS) [105]. CTLA-4 expression in both tumor cells and TILs was associated with worse DFS and OS in luminal B HER2- BC [106]. A flow cytometry study investigating the intracellular protein expression of CTLA- 4 by BC CD $4^{+}$TILs revealed its almost low expression in the luminal versus HER2-positive and TNBC subtypes, as a consequence of their lower baseline immune infiltration [107].

\subsection{Highlights of PD1/PD-L1 and HR+ BC}

One of the well-recognized immune-checkpoints associated with immune evasion in BC is programmed cell death-1 (PD-1) and its ligand PD-L1 axis [108]. PD-1, which is mainly expressed on the surface of the T-cell membrane, when combined with PD-L1 induces T-cell apoptosis and promotes T-cell differentiation towards Tregs [109].

Innate absence of PD-L1 expression is associated with immune hyperactivity against self, such as that observed in autoimmune diseases such as systemic lupus erythematosus [110]. Consequently, it has been thought that the upregulation of PD-L1 in tumor cells (a rare phenomenon in BC) could be related to tumor immune evasion [61, 111]. PD-L1 mRNA was found to be expressed in at least $20 \%$ of BC cells [112] and the majority of tumors that upregulated PD-L1 are HR- (52\% vs. 48\%) [112, 113]. Many studies have relatively consistently reported that $\mathrm{PD}-\mathrm{L} 1$ represents a good survival prognostic factor in TNBC [114-119], whereas the clinical role of PD-L1 is not clear in HR+ patients [61]. About $8-45 \%$ of $\mathrm{HR}+\mathrm{BC}$ express PD-L1 [60]. Interestingly, Wu et al. recently demonstrated that in $\mathrm{HR}+$ patients, PD-L1 expression was associated with better pCR $(p=0.022)$, but with poor DFS ( $p=0.018)$ [120]. Considering that PD-L1 
expression is positively correlated with the extent of TILs, these findings are in line with the meta-analysis by Denkert et al. revealing that high TILs are associated with worse survival outcomes in luminal BC. Further, a large comprehensive meta-analysis revealed that whereas in HER2-positive and TNBC we can observe a statistically significant correlation between $\mathrm{pCR}$ and survival, in $\mathrm{HR}+\mathrm{BC}$, there is no correlation [121]. Moreover, PD-L1 seems to provide additional favorable prognostic value to 21 - and 70-gene scores in HR+ BC [122].

Based on these considerations, we may deduce that high TIL luminal BC are more likely to respond to neo-adjuvant chemotherapy compared to low TIL BC, but present more aggressive features that confer a worse prognosis. The explanation of this phenomenon might be found by examining the composition of the immune infiltrate.

\subsection{The Role of Fas/Fas-Ligand (FasL) Pathway in BC Immunoevasion}

The role of Tregs in the process of immune evasion is crucial. Tumor cells release the chemokines that attract Tregs into the tumor. Once these suppressive cells are recruited, they start to inhibit the function of Th cells stimulated against cancer cells, thus having a pro-tumoral effect. For example, they can induce Th cell apoptosis activating the Fas-Fas Ligand (FasL) pathway.

Fas (also known as APO-1 or CD95) belongs to the subgroup of the tumor necrosis factor receptor (TNF-R) family that contains an intra-cellular "death domain," and can trigger apoptosis. Its physiological ligand, FasL (CD95L), is a member of the corresponding TNF cytokine family [123].

The Fas death receptor is displayed on the surfaces of several types of lymphocytes, and by the activation of this extrinsic apoptotic pathway (=Fas-FasL) CTL are destroyed. Tumor cells can produce and release soluble forms of the apoptosis-inducing protein CD95L (FasL, APO-1L, CD178), thus eliminating TIL and suppressing anti-tumor immune responses, a phenomenon called "tumor counterattack" [124]. The upregulation of FasL often occurs following CT, from which tumor cells have attained apoptosis resistance [125].

Interestingly, in a TiRP melanoma model, Zhu J et al. showed that TIL apoptosis was mediated by polymorphonuclear-myeloid-derived suppressor cells (PM-MDSCs) through FasL. Similarly, Tregs trigger apoptosis of CD $8^{+}$ cells by the high expression of FasL determining immune tolerance [126].

Several studies suggest that the downregulation of Fas in EBC is associated with a worse prognosis [127]. Mottolese et al. revealed that the DFS was significantly longer in patients with Fas-positive tumors compared to the Fasnegative ones [128]. These results were further confirmed by Reimer et al. and Botti et al., who found that the FasL:Fas ratio $>1$ was related to a significantly shorter DFS [129, 130].

Furthermore, T and FasL:Fas ratio were of independent predictive significance in the multivariate model for DFS and OS in that subgroup. Among postmenopausal patients $(n=148)$, these factors retained independent prognostic significance in the multivariate model for DFS [129]. Based on these considerations, we can conclude that the expression of FasL is associated with a worse prognosis in HR+ EBC.

\section{Clinical Trials with Immune Checkpoint Blockade (ICB) in HR+ BC}

Several early phase trials have tested the safety and efficacy of immunotherapy alone or in combination with other agents in luminal BC patients (Tables 1, 2). In the neoadjuvant setting, pembrolizumab - in combination with chemotherapyincreased the pCR rates, varying from 15 to $30 \%$, depending on the chemotherapy backbone [131]. In the advanced setting, ORR ranges from $12 \%$ for pembrolizumab alone [132] to $34 \%$ in association with eribulin [133] and $29 \%$ when combined with the CDK4/6i, abemaciclib [134]. As maintenance therapy, durvalumab (i.e., anti-PD-L1 antibody) improved OS compared to chemotherapy in $\mathrm{HR}+\mathrm{BC}(21.7$ vs. 17.9) [135].

In order to improve the efficacy of immune activation in this subset of patients, several studies are currently testing the efficacy of ICB in this subtype. They are summarized in Table 3. Most of the trials are administering combination regimens in order to synergize the ICB effect. In this context, anti-PD-L1 is provided with anti-CTLA4 monoclonal antibodies (mAbs) (NCT03132467, NCT03608865) or with oncolytic virus (i.e., in the NCT03802604 trial), administered with the aim of increasing the immune infiltration at the tumor site.

Scientists are also trying to use the immunomodulatory and antigenic exposure effect of CT in order to enhance the activity of ICB. Previous findings demonstrated that the therapeutic efficacy of doxorubicin treatment is dependent on IL-1b, IL-17, and interferon gamma (IFN $\gamma$ ) production, and $\mathrm{CD} 8^{+}$cell recruitment. The efficacy of eribulin may be attributed to its biological effects on the immune system, such as the reduction of PD-L1 and FOXP3 expression [136, 137], shifting the balance from a pro- to an anti-tumor immune response. Furthermore, the immune-modulating effects of taxanes appear to synergize with ICB. In particular, the reduction in Tregs and MDSCs paired with the recruitment of $\mathrm{T}$ cells and mature DCs to the tumor could render ICB-induced $\mathrm{T}$ cells more effective within the TME [138]. 
Table 1 Completed clinical trials with immune checkpoint inhibitors in hormone receptor-positive early breast cancer

\begin{tabular}{|c|c|c|c|c|c|c|}
\hline $\begin{array}{l}\text { ClinicalTrials. } \\
\text { govIdentifier }\end{array}$ & Setting & Phase & Treatment arm(s) & ORR $(\%)$ & Survival (months) & $\begin{array}{l}\text { Grade } 3 / 4 \mathrm{AE} \\
\text { prevalence }(\%)\end{array}$ \\
\hline NCT01042379 & Neoadjuvant & 2 & $\begin{array}{l}\text { Pembrolizumab four-arm /placebo + paclitaxel fol- } \\
\text { lowed by doxorubicin }+ \text { ciclofosfamide }\end{array}$ & NR & pCR $30 \%$ vs. $13 \%$ & 25 \\
\hline NCT01042379 & Neoadjuvant & 2 & $\begin{array}{l}\text { Pembrolizumab } 8 \text { weekly paclitaxel x } 12 \text { wks }+ \\
\text { pembrolizumab q3 wks x } 4 \text { followed by pembroli- } \\
\text { zumab q } 3 \text { wks x } 4\end{array}$ & NR & Non TNBC pCR 15 & NR \\
\hline
\end{tabular}

$A E$ adverse event, $p C R$ pathological complete response, $N R$ not reported, $T N B C$ triple negative breast cancer

Based on these considerations, the following trials are NCT03393845, NCT03225547, NCT02990845,

Table 2 Completed clinical trials with immune checkpoint inhibitors in hormone receptor-positive advanced breast cancer

\begin{tabular}{|c|c|c|c|c|c|c|}
\hline $\begin{array}{l}\text { ClinicalTrials. } \\
\text { govIdentifier }\end{array}$ & Setting & Phase & Treatment arm(s) & ORR $(\%)$ & Survival (mths) & $\begin{array}{l}\text { Grade } 3 / 4 \mathrm{AE} \\
\text { prevalence }(\%)\end{array}$ \\
\hline NCT02054806 & $2 \mathrm{~L}+$ & $1 \mathrm{~b}$ & Pembrolizumab & 12 & $\begin{array}{l}\text { mDOR } 12 \\
\text { mPFS } 1.8 \\
\text { mOS } 8.6\end{array}$ & 16 \\
\hline NCT03051659 & $2 \mathrm{~L}+$ & 2 & Pembrolizumab + eribulin vs. Eribulim & 25 vs. 34 & mPFS 4.1 vs. 4.2 & $54.6 \mathrm{vs}$ \\
\hline NCT02299999 & $1 \mathrm{~L}$ or $2 \mathrm{~L}$ & 2 & $\begin{array}{l}\text { In patients with } \mathrm{CR} / \mathrm{PR} / \mathrm{SD} \text { after } 6-8 \mathrm{CT} \text { cycles and } \\
\text { no targetable molecular alteration randomization } \\
\text { to durvalumab or maintenance } \mathrm{CT}\end{array}$ & 39.7 vs. 42.6 & $\begin{array}{l}\text { ITT } \\
\text { mPFS } 2.7 \text { vs. } 4.6 \\
\text { mOS } 21.7 \text { vs. } 17.9\end{array}$ & 13.2 vs. 15.9 \\
\hline NCT02779751 & $2 \mathrm{~L}$ & $1 b$ & Pembrolizumab + abemaciclib & 28.6 & NR & NR \\
\hline
\end{tabular}

$A E$ adverse event, $P F S$ progression-free survival, $O S$ overall survival

testing the efficacy of CT in association with ICB, in both the early and the advanced settings of the HR+ disease. They are: NCT03515798, NCT02957968, NCT03815890, NCT03356860, NCT03875573, NCT02999477, NCT02018458, NCT03725059, NCT03591276, NCT03841747, NCT03222856, NCT03409198, NCT02614833. Furthermore, the radiation-induced activation of the immune system has been increasingly recognized in recent years, suggesting that RT could also elicit immunemediated anti-tumor responses $[139,140]$. In fact, the role of T lymphocytes in the local tumor control induced by RT was demonstrated in a murine fibrosarcoma model more than 30 years ago $[139,140]$. Other studies have found that this immune-mediated anti-tumor effect of RT could also trigger the regression of metastatic tumors that were distant from the irradiated field, which is the so-called abscopal effect $[139,141]$. Consequently, RT has been associated with ICB in several clinical trials enrolling HR+ BC patients (NCT03366844 and NCT03051672).

Moreover, the HT aromatase inhibitors-in particular letrozole-seem to reduce the presence of intratumoral FOXP3 $^{+}$Tregs [142]; in this context, several trials are administering ICB in combination with aromatase inhibitors (NCT03874325, NCT02997995, NCT02204098, NCT03804944, NCT02971748, NCT03879174,
NCT02648477, NCT03430479, NCT03430466).

Preclinical evidence suggests that CDK4/6 inhibitors (CDK4/6i) promote anti-tumor immunity by increasing antigen processing and presentation [143]. They may also modulate NK cell activity, augment T-cell effector function, and markedly suppress the proliferation of Tregs. A phase Ib study of the anti-PD-1 pembrolizumab plus abemaciclib in heavily pretreated patients with PD-L1-positive $\mathrm{HR}+$ advanced $\mathrm{BC}$ showed an acceptable safety profile and a clinical activity (overall response rate: $14.3 \%$ at 16 weeks with a $75 \%$ disease control rate) [144]. Considering these results, further studies are now ongoing combining ICB and CDK4/6i (NCT02778685, NCT03147287, NCT03294694).

\section{Conclusions}

In summary, TME has a peculiar role in $\mathrm{HR}+\mathrm{BC}$ which seems to differ from other BC subtypes. In particular, in luminal/HER2-negative tumors, high TIL extent was a negative prognostic factor, and the total number of infiltrating $\mathrm{CD} 8^{+}$cells was not significantly associated with patient outcome. Conversely, high tumor-infiltrating $\mathrm{FOXP}^{+} \mathrm{T}$ cells has been associated with shorter OS, identifying patients with high risk of late-relapse within this subgroup. CTLA-4 
Table 3 Currently ongoing clinical trials with immune checkpoint inhibitors in hormone receptor-positive early breast cancer

\begin{tabular}{|c|c|c|c|c|}
\hline $\begin{array}{l}\text { ClinicalTrials. } \\
\text { gov Identifier }\end{array}$ & Setting & Phase & Primary endpoint(s) & Treatment $\operatorname{arm}(\mathrm{s})$ \\
\hline NCT03515798 & Neoadjuvant & 2 & pCR, DLT & $\begin{array}{l}\text { Experimental arm: pembrolizumab+(F)EC } \\
\text { followed by paclitaxel. Control arm: (F)EC } \\
\text { followed by paclitaxel }\end{array}$ \\
\hline NCT02957968 & Neoadjuvant & 2 & TIL & $\begin{array}{l}\text { Decitabine+pembrolizumab followed by dose- } \\
\text { dense ACx } 4 \text { followed by paclitaxel weekly } \\
\text { x } 12\end{array}$ \\
\hline NCT03395899 & Neoadjuvant & 2 & $\begin{array}{l}\text { 2-fold Increase in GzmB+CD8+ T cell } \\
\text { levels }\end{array}$ & $\begin{array}{l}\text { Control arm: atezolizumab. Three experimental } \\
\text { arms: (1) atezolizumab + cobimetinib, (2) } \\
\text { atezolizumab + ipatasertib, (3) atezolizumab } \\
\text { + cobimetinib + bevacizumab }\end{array}$ \\
\hline NCT03815890 & Neoadjuvant & 2 & $\begin{array}{l}\text { Immune activation after pre-operative } \\
\text { nivolumab }\end{array}$ & $\begin{array}{l}\text { Cohort 1: nivolumab; cohort 2: } \\
\text { nivolumab+doxorubicin }\end{array}$ \\
\hline NCT03132467 & Neoadjuvant & 1 & Feasibility, Safety & Durvalumab+tremelimumab \\
\hline NCT03356860 & Neoadjuvant & $1 / 2$ & Toxicity, pCR & $\begin{array}{l}\text { Experimental arm: durvalumab + chemo- } \\
\text { therapy (paclitaxel then EC). Control arm: } \\
\text { chemotherapy (paclitaxel then EC) }\end{array}$ \\
\hline NCT03874325 & Neoadjuvant & 2 & Rate mPEPI score of 0 & Durvalumab + aromatase Inhibitor \\
\hline NCT02997995 & Neoadjuvant & 2 & $\mathrm{pCR}$ & $\begin{array}{l}\text { Tremelimumab + exemestane, followed by } \\
\text { durvalumab + exemestane }\end{array}$ \\
\hline NCT03875573 & Neoadjuvant & 2 & Safety, residual cancer burden & $\begin{array}{l}\text { Control arm: paclitaxel followed by dose-dense } \\
\text { doxorubicin-cyclophosphamide (ddAC) } \\
\text { and pre-operative RT. Experimental arm } \\
\text { 1: durvalumab + control arm treatment. } \\
\text { Experimental arm 2: oleclumab + control } \\
\text { arm treatment }\end{array}$ \\
\hline NCT02999477 & Neoadjuvant & 1 & $\begin{array}{l}\text { Change in PD-L1 expression by IHC from } \\
\text { baseline biopsy to biopsy after 2-week } \\
\text { treatment }\end{array}$ & Pembrolizumab + nab-paclitaxel \\
\hline NCT03366844 & Neoadjuvant & 1 & Safety, changes in TIL & Pembrolizumab+RT \\
\hline NCT02204098 & Neoadjuvant & 1 & Safety & $\begin{array}{l}\text { Control arm Cohort 1: neoadjuvant endocrine } \\
\text { therapy. Experimental arm Cohort 2: neoad- } \\
\text { juvant endocrine + mammaglobin-A DNA } \\
\text { vaccine. Control arm Cohort 3: neoadjuvant } \\
\text { chemotherapy. Experimental arm Cohort 4: } \\
\text { neoadj chemotherapy + mammaglobin-A } \\
\text { DNA vaccine. }\end{array}$ \\
\hline NCT02018458 & Neoadjuvant & $1 / 2$ & Safety & $\mathrm{DC}$ vaccine + chemotherapy $\mathrm{AC}$ \\
\hline NCT03802604 & Neoadjuvant & 2 & Gene signature CD8 Tc & Talimogene laherparepvec + atezolizumab \\
\hline NCT03804944 & Neoadjuvant/Adjuvant & 2 & Safety, clinical and pathological RR & $\begin{array}{l}\text { Arm 1: RT; Arm 2: RT + pembrolizumab; Arm } \\
\text { 3: RT+CDX301; Arm 4: RT + pembroli- } \\
\text { zumab + CDX301 (all arms: Letrozole until } \\
\text { surgery, and thereafter decided by the treating } \\
\text { physician) }\end{array}$ \\
\hline NCT03725059 & Neoadjuvant/ Adjuvant & 3 & pCR, EFS & $\begin{array}{l}\text { Experimental arm: Pembrolizumab + chemo- } \\
\text { therapy }(\mathrm{KX} / \mathrm{KA}[\mathrm{E}] \mathrm{C}) \text {. Control arm: Placebo } \\
\text { + chemotherapy }(\mathrm{PX} / \mathrm{PA}[\mathrm{E}] \mathrm{C})\end{array}$ \\
\hline NCT02971748 & Adjuvant & 2 & DFS & Pembrolizumab + hormonal therapy \\
\hline NCT03879174 & Advanced & 2 & PFS, ORR & Pembrolizumab + tamoxifen \\
\hline NCT03393845 & Advanced & 2 & ORR & Pembrolizumab + fulvestrant \\
\hline NCT03225547 & Advanced & 2 & ORR & Pembrolizumab + mifepristone \\
\hline NCT03591276 & Advanced & 1 & Safe dose doxil, ORR & $\begin{array}{l}\text { Pembrolizumab + pegylated liposomal doxo- } \\
\text { rubicin }\end{array}$ \\
\hline NCT03841747 & Advanced & 2 & PFS, OS & $\begin{array}{l}\text { Experimental arm: pembrolizumab + pacli- } \\
\text { taxel. Control arm: paclitaxel }\end{array}$ \\
\hline NCT02990845 & Advanced & $1 / 2$ & PFS at 8 months & Pembrolizumab + exemestane + leuprolide \\
\hline
\end{tabular}


Table 3 (continued)

\begin{tabular}{|c|c|c|c|c|}
\hline $\begin{array}{l}\text { ClinicalTrials. } \\
\text { gov Identifier }\end{array}$ & Setting & Phase & Primary endpoint(s) & Treatment $\operatorname{arm}(\mathrm{s})$ \\
\hline NCT03222856 & Advanced & 2 & CBR & Pembrolizumab + eribulin \\
\hline NCT02778685 & Advanced & 2 & ORR & Pembrolizumab + letrozole + palbociclib \\
\hline NCT02648477 & Advanced & 2 & Safety, ORR in cohort 1, ORR in cohort 2 & Pembrolizumab + AI \\
\hline NCT03566485 & Advanced & $1 / 2$ & DLT, MTD, RP2D, ORR & $\begin{array}{l}\text { Arm 1: atezolizumab + cobimetinib; Arm 2: } \\
\text { atezolizumab + idasanutlin }\end{array}$ \\
\hline NCT03280563 & Advanced & $1 / 2$ & ORR & $\begin{array}{l}\text { Control arm: fulvestrant. Experimental arm: } \\
\text { atezolizumab-containing doublet or triplet } \\
\text { combination (enotinostat/ipatasertib/ipata- } \\
\text { sertib + fulvestrant/fulvestrant/bevacizumab } \\
\text { + ET) (stage 1). Subsequent triplet combina- } \\
\text { tion (stage 2) }\end{array}$ \\
\hline NCT03409198 & Advanced & 2 & Toxicity, PFS & $\begin{array}{l}\text { Control arm: pegylated liposomal doxorubicin } \\
\text { + cyclophosphamide. Experimental arm: } \\
\text { pegylated liposomal doxorubicin + cyclo- } \\
\text { phosphamide +ipilimumab + nivolumab }\end{array}$ \\
\hline NCT03430479 & Advanced & $1 / 2$ & DLT & Nivolumab + radiotherapy + hormonal therapy \\
\hline NCT03608865 & Advanced & 2 & ORR & Durvalumab + tremelimumab \\
\hline NCT03430466 & Advanced & 2 & ORR & Durvalumab + tremelimumab + fulvestrant \\
\hline NCT03147287 & Advanced & 2 & PFS & $\begin{array}{l}\text { Control arm: fulvestrant. Experimental arm 1: } \\
\text { Palbociclib + fulvestrant. Exlerimental arm } \\
\text { 2: avelumab + Palbociclib + fulvestrant }\end{array}$ \\
\hline NCT02614833 & Advanced & $1 / 2$ & RP2D, PFS & $\begin{array}{l}\text { Control arm: paclitaxel + placebo. Experimen- } \\
\text { tal arm: paclitaxel+IMP321 }\end{array}$ \\
\hline NCT03051672 & Advanced & 2 & ORR & Pembrolizumab+RT \\
\hline NCT03294694 & Advanced & 1 & MTD/RP2D & $\begin{array}{l}\text { Cohort A: Ribociclib + PDR001; cohort B: } \\
\text { Ribociclib + PDR001 + fulvestrant }\end{array}$ \\
\hline
\end{tabular}

$p C R$ pathological complete response, $T I L$ tumor-infiltrating lymphocytes, $I H C$ immunohistochemical, $D F S$ disease-free survival, $P F S$ progression-free survival,

expression in both tumor cells and TILs was associated with worse DFS and OS in luminal B HER2-negative BC. Similarly, PD-L1 expression was associated with poor DFS. Several studies suggest that the downregulation of Fas in $\mathrm{HR}+$ $\mathrm{EBC}$ is also associated with worse prognosis.

Based on the previous observations, several trials are currently testing the efficacy of ICB in $\mathrm{HR}+\mathrm{BC}$ and results are awaited to confirm the potential therapeutic role of the immunomodulation in this subgroup of patient. As the majority of the observations regarding the TME and its role in $\mathrm{HR}+\mathrm{BC}$ are retrospective, we strongly encourage prospective, translational trials aimed to dissect this topic.

Acknowledgements Authors thank Dr David Gray for assistance in writing in English.

\section{Declarations}

Funding Open access funding provided by Università degli Studi di Parma within the CRUI-CARE Agreement. B.P. was supported by ESMO with a Clinical Translational Fellowship aid supported by Roche. Any views, opinions, findings, conclusions, or recommenda- tions expressed in this material are those solely of the authors and do not necessarily reflect those of ESMO or Roche.

Conflict of interest CM: The opinions expressed in this article are the personal views of the author and may not be understood or quoted as being made on behalf of or reflecting the position of the Italian Medicines Agency (AIFA). AM: Reports grants and personal fees from Roche, personal fees from Lilly, grants from Eisai, personal fees from Novartis, personal fees from Macrogenics, outside the submitted work. BP, ZH, PDS, MA, KWG, and CS have no conflicts of interest to declare.

Ethics approval Not applicable.

Consent NA.

Data and code availability NA.

Authors' contributions All the authors substantially contributed to the conception of the work. BP, ZH, PDS, CM, and CS drafted the work and all the authors revised it critically for important intellectual content. All the authors finally approved the version published.

Open Access This article is licensed under a Creative Commons Attribution-NonCommercial 4.0 International License, which permits any non-commercial use, sharing, adaptation, distribution and reproduction 
in any medium or format, as long as you give appropriate credit to the original author(s) and the source, provide a link to the Creative Commons licence, and indicate if changes were made. The images or other third party material in this article are included in the article's Creative Commons licence, unless indicated otherwise in a credit line to the material. If material is not included in the article's Creative Commons licence and your intended use is not permitted by statutory regulation or exceeds the permitted use, you will need to obtain permission directly from the copyright holder. To view a copy of this licence, visit http://creativecommons.org/licenses/by-nc/4.0/.

\section{References}

1. Ferlay J, Shin HR, Bray F, Forman D, Mathers C, Parkin DM. Estimates of worldwide burden of cancer in 2008: GLOBOCAN 2008. Int J Cancer. 2010;127:2893-917.

2. Bray F, Ferlay J, Soerjomataram I, Siegel RL, Torre LA, Jemal A. Global cancer statistics 2018: GLOBOCAN estimates of incidence and mortality worldwide for 36 cancers in 185 countries. CA Cancer J Clin. 2018;68:394-424.

3. Public Health England (PHE). Survival by stage. Stage Break by CCG 2016. 2018. http://www.ncin.org.uk/publications/survival_ by_stage. Accessed 24 Apr 2020.

4. Cancer I Detect Cancer Early I Health Topics I ISD Scotland. https://www.isdscotland.org/Health-Topics/Cancer/Detect-Cancer-Early/. Accessed 24 Apr 2020.

5. Queen's University Belfast. Queen's University Belfast I N. Ireland Cancer Registry I Official Statistics. N. Irel. Cancer Regist. https://www.qub.ac.uk/research-centres/nicr/CancerInformation/ official-statistics/. Accessed 24 Apr 2020.

6. SEER Survival Statistics - SEER Cancer Query Systems. https:// seer.cancer.gov/canques/survival.html. Accessed 4 Apr 2020.

7. https://www.csg.lshtm.ac.uk/. Accessed 4 Apr 2020.

8. Denkert C, von Minckwitz G, Darb-Esfahani S, Lederer B, Heppner BI, Weber KE, et al. Tumour-infiltrating lymphocytes and prognosis in different subtypes of breast cancer: a pooled analysis of 3771 patients treated with neoadjuvant therapy. Lancet Oncol [Internet]. 2018;19:40-50 (cited 2019 Apr 7).

9. Schmid P, Adams S, Rugo HS, Schneeweiss A, Barrios CH, Iwata $\mathrm{H}$, et al. Atezolizumab and Nab-paclitaxel in advanced triplenegative breast cancer. N Engl J Med [Internet]. 2018;379:210821. https://doi.org/10.1056/NEJMoa1809615 (cited 2020 Apr 4).

10. Schmid P, Cortes J, Pusztai L, McArthur H, Kümmel S, Bergh $\mathrm{J}$, et al. Pembrolizumab for early triple-negative breast cancer. $\mathrm{N}$ Engl J Med [Internet]. 2020;382:810-21 (cited 2020 Mar 31).

11. Wolchok JD, Hoos A, O'Day S, Weber JS, Hamid O, Lebbé C, et al. Guidelines for the evaluation of immune therapy activity in solid tumors: immune-related response criteria. Clin Cancer Res [Internet]. 2009;15:7412-20 (cited 2021 Feb 12).

12. Martins F, Sofiya L, Sykiotis GP, Lamine F, Maillard M, Fraga $\mathrm{M}$, et al. Adverse effects of immune-checkpoint inhibitors: epidemiology, management and surveillance [Internet]. Nat Rev Clin Oncol. Nature Publishing Group; 2019 [cited 2021 Feb 12]. p. 563-80. http://www.nature.com/nrclinonc.

13. Porcu M, De Silva P, Solinas C, Battaglia A, Schena M, Scartozzi $\mathrm{M}$, et al. Immunotherapy Associated Pulmonary Toxicity: Biology Behind Clinical and Radiological Features. Cancers (Basel) [Internet]. 2019;11:305.

14. Garon-Czmil J, Petitpain N, Rouby F, Sassier M, Babai S, Yéléhé-Okouma M, et al. Immune check point inhibitors-induced hypophysitis: a retrospective analysis of the French Pharmacovigilance database. Sci Rep [Internet]. 2019;9:1-5 (cited 2021 Feb 12).
15. Porcu M, Solinas C, Garofalo P, de Azambuja E, Scartozzi M, Willard-Gallo K, et al. Radiological evaluation of response to immunotherapy in brain tumors: Where are we now and where are we going? [Internet]. Crit Rev Oncol. Hematol. Elsevier Ireland Ltd; 2018 [cited 2020 Apr 17]. p. 135-44. http://www.ncbi. nlm.nih.gov/pubmed/29759556.

16. Solinas C, Gombos A, Latifyan S, Piccart-Gebhart M, Kok M, Buisseret L. Targeting immune checkpoints in breast cancer: an update of early results. ESMO Open [Internet]. 2017;2:e000255 (cited 2019 Apr 7).

17. Solinas C, De Silva P, Bron D, Willard-Gallo K, Sangiolo D. Significance of TIM3 expression in cancer: From biology to the clinic [Internet]. Semin. Oncol. W.B. Saunders; 2019 [cited 2020 Apr 17]. p. 372-9. http://www.ncbi.nlm.nih.gov/pubmed/31733 828.

18. Vinayak S, Tolaney SM, Schwartzberg L, Mita M, McCann G, Tan AR, et al. Open-label clinical trial of niraparib combined with pembrolizumab for treatment of advanced or metastatic triple-negative breast cancer. JAMA Oncol [Internet]. 2019/06/14. Case Comprehensive Cancer Center, University Hospitals, Case Western Reserve University, Cleveland, Ohio. currently affiliated with Fred Hutchinson Cancer Research Center, Division of Oncology, University of Washington School of Medicine, Seattle Cancer C; 2019. https://www.ncbi.nlm.nih.gov/pubmed/31194 225.

19. Brignone C, Gutierrez M, Mefti F, Brain E, Jarcau R, Cvitkovic $\mathrm{F}$, et al. First-line chemoimmunotherapy in metastatic breast carcinoma: Combination of paclitaxel and IMP321 (LAG-3Ig) enhances immune responses and antitumor activity. J Transl Med [Internet]. J Transl Med; 2010 [cited 2021 Feb 12];8. https:// pubmed.ncbi.nlm.nih.gov/20653948/.

20. Vonderheide RH, Lorusso PM, Khalil M, Gartner EM, Khaira D, Soulieres D, et al. Tremelimumab in combination with exemestane in patients with advanced breast cancer and treatment-associated modulation of inducible costimulator expression on patient T cells. Clin Cancer Res [Internet]. 2010;16:3485-94 (cited 2021 Feb 12).

21. Solinas C, Aiello M, Migliori E, Willard-Gallo K, Emens LA. Breast cancer vaccines: heeding the lessons of the past to guide a path forward [Internet]. Cancer Treat. Rev. W.B. Saunders Ltd; 2020 [cited $2020 \mathrm{Jul}$ 27]. https://pubmed.ncbi.nlm.nih.gov/31926 $403 /$.

22. O’Meara T, Marczyk M, Qing T, Yaghoobi V, Blenman K, Cole $\mathrm{K}$, et al. Immunological differences between immune-rich estrogen receptor-positive and immune-rich triple-negative breast cancers. JCO Precis Oncol [Internet]. 2020;4:767-79 (cited 2021 Feb 15).

23. Carter CL, Allen C, Henson DE. Relation of tumor size, lymph node status, and survival in 24,740 breast cancer cases. Cancer. 1989;63:181-7.

24. Fisher B, Bauer M, Wickerham DL, Redmond CK, Fisher ER, Cruz AB, et al. Relation of number of positive axillary nodes to the prognosis of patients with primary breast cancer. An NSABP update. Cancer. 1983;52:1551-7.

25. Le Doussal V, Tubiana-Hulin M, Friedman S, Hacene K, Spyratos F, Brunet M. Prognostic value of histologic grade nuclear components of Scarff-Bloom-Richardson (SBR). An improved score modification based on a multivariate analysis of 1262 invasive ductal breast carcinomas. Cancer [Internet]. 1989;64:191421 (cited 2020 Apr 4).

26. Inwald EC, Klinkhammer-Schalke M, Hofstädter F, Zeman F, Koller M, Gerstenhauer M, et al. Ki-67 is a prognostic parameter in breast cancer patients: results of a large populationbased cohort of a cancer registry. Breast Cancer Res Treat. 2013;139:539-52. 
27. Cristofanilli M, Valero V, Buzdar AU, Kau SW, Broglio KR, Gonzalez-Angulo AM, et al. Inflammatory breast cancer (IBC) and patterns of recurrence: understanding the biology of a unique disease. Cancer [Internet]. 2007;110:1436-44 (cited 2020 Apr 4).

28. Diab SG, Clark GM, Osborne CK, Libby A, Allred DC, Elledge RM. Tumor characteristics and clinical outcome of tubular nad mucinous breast carcinomas. J Clin Oncol. 1999;17:1442-8.

29. Railo M, Lundin J, Haglund C, Von Smitten K, Von Boguslawsky K, Nordling S. Ki-67, p53, Er-receptors, ploidy and S-phase as prognostic factors in $\mathrm{T} 1$ node negative breast cancer. Acta Oncol (Madr) [Internet]. 1997;36:369-74 (cited 2020 Apr 4).

30. Tamoxifen for early breast cancer: an overview of the randomised trials. Early Breast Cancer Trialists' Collaborative Group. Lancet (London, England) [Internet]. 1998 [cited 2020 Apr 4];351:1451-67. http://www.ncbi.nlm.nih.gov/pubmed/9605801.

31. Tsutsui S, Ohno S, Murakami S, Hachitanda Y, Oda S. Prognostic value of c-erbB2 expression in breast cancer. J Surg Oncol [Internet]. 2002;79:216-23 (cited 2020 Apr 4).

32. Perou CM, Sørlie T, Eisen MB, van de Rijn M, Jeffrey SS, Rees CA, et al. Molecular portraits of human breast tumours. Nature. 2000;406:747-52.

33. Kennecke H, Yerushalmi R, Woods R, Cheang MCU, Voduc D, Speers $\mathrm{CH}$, et al. Metastatic behavior of breast cancer subtypes. J Clin Oncol [Internet]. 2010;28:3271-7. https://doi.org/10.1200/ JCO.2009.25.9820 (cited 2021 Feb 11).

34. Sledge GW, Toi M, Neven P, Sohn J, Inoue K, Pivot X, et al. The Effect of abemaciclib plus fulvestrant on overall survival in hormone receptor-positive, ERBB2-negative breast cancer that progressed on endocrine therapy-MONARCH 2: a randomized clinical trial. JAMA Oncol [Internet]. 2020;6:116-24 (cited 2021 Feb 11).

35. Slamon DJ, Neven P, Chia S, Fasching PA, De Laurentiis M, Im SA, et al. Overall survival with ribociclib plus fulvestrant in advanced breast cancer. N Engl J Med [Internet]. 2020;382:51424. https://doi.org/10.1056/NEJMoa1911149 (cited 2020 Jun 27).

36. Albain KS, Barlow WE, Shak S, Hortobagyi GN, Livingston $\mathrm{RB}$, Yeh IT, et al. Prognostic and predictive value of the 21-gene recurrence score assay in postmenopausal women with nodepositive, oestrogen-receptor-positive breast cancer on chemotherapy: a retrospective analysis of a randomised trial. Lancet Oncol. 2010;11:55-65.

37. Van't Veer LJ, Dai H, Van de Vijver MJ, He YD, Hart AAM, Mao $\mathrm{M}$, et al. Gene expression profiling predicts clinical outcome of breast cancer. Nature. 2002;415:530-6.

38. Wallden B, Storhoff J, Nielsen T, Dowidar N, Schaper C, Ferree $\mathrm{S}$, et al. Development and verification of the PAM50-based Prosigna breast cancer gene signature assay. BMC Med Genomics [Internet]. 2015;8:54 (cited 2020 Apr 4).

39. Bartlett JMS, Sgroi DC, Treuner K, Zhang Y, Ahmed I, Piper $\mathrm{T}$, et al. Breast Cancer Index and prediction of benefit from extended endocrine therapy in breast cancer patients treated in the Adjuvant Tamoxifen-To Offer More? (aTTom) trial. Ann Oncol [Internet]. 2019;30:1776-83 (cited 2021 Feb 11).

40. Gray E, Marti J, Brewster DH, Wyatt JC, Hall PS. Independent validation of the PREDICT breast cancer prognosis prediction tool in 45,789 patients using Scottish Cancer Registry data. $\mathrm{Br}$ J Cancer [Internet]. 2018;119:808-14. https://doi.org/10.1038/ s41416-018-0256-x (cited 2021 Feb 11)

41. Wishart GC, Azzato EM, Greenberg DC, Rashbass J, Kearins O, Lawrence G, et al. PREDICT: a new UK prognostic model that predicts survival following surgery for invasive breast cancer. Breast Cancer Res [Internet]. 2010;12:R1. https://doi.org/10. 1186/bcr2464 (cited 2021 Feb 11).
42. Cuzick J, Dowsett M, Pineda S, Wale C, Salter J, Quinn E, et al. Prognostic value of a combined estrogen receptor, progesterone receptor, Ki-67, and human epidermal growth factor receptor 2 immunohistochemical score and comparison with the genomic health recurrence score in early breast cancer. J Clin Oncol [Internet]. 2011;29:4273-8 (cited 2021 Feb 11).

43. Jin L, Chen K, Tan C, Li J, Luo J, Yang Y, et al. Prognostic Value of Modified IHC4 Score in Patients with Estrogen Receptor-Positive Metastatic Breast Cancer . Oncologist [Internet]. Wiley; 2020 [cited $2021 \mathrm{Feb}$ 11];25. https://pubmed.ncbi.nlm. nih.gov/32476192/.

44. Lee J, Cha C, Ahn SG, Kim D, Park S, Bae SJ, et al. Validation of Clinical Treatment Score post-5 years (CTS5) risk stratification in premenopausal breast cancer patients and Ki-67 labelling index. Sci Rep [Internet]. 2020;10:16850. https://doi.org/ 10.1038/s41598-020-74055-3 (cited 2021 Feb 12).

45. Bhargava R, Clark BZ, Carter GJ, Brufsky AM, Dabbs DJ. The healthcare value of the Magee Decision Algorithm ${ }^{\mathrm{TM}}$ : use of Magee Equations ${ }^{\mathrm{TM}}$ and mitosis score to safely forgo molecular testing in breast cancer. Mod Pathol [Internet]. Springer Nature; 2020 [cited 2021 Feb 12];33:1563-70. https://doi.org/10.1038/ s41379-020-0521-4.

46. Almstedt K, Mendoza S, Otto M, Battista MJ, Steetskamp J, Heimes AS, et al. EndoPredict ${ }^{\circledR}$ in early hormone receptorpositive, HER2-negative breast cancer. Breast Cancer Res Treat [Internet]. Springer; 2020 [cited $2021 \mathrm{Feb} 12$ ];182:137-46. https://doi.org/10.1007/s10549-020-05688-1.

47. Wolmark N, Mamounas EP, Baehner FL, Butler SM, Tang G, Jamshidian F, et al. Prognostic impact of the combination of recurrence score and quantitative estrogen receptor expression (ESR1) on predicting late distant recurrence risk in estrogen receptor-positive breast cancer after 5 years of tamoxifen: Results from NRG oncology/national surgical adjuvant breast and bowel project B-28 and B-14. J Clin Oncol [Internet]. American Society of Clinical Oncology; 2016 [cited 2021 Feb 11];34:2350-8. / pmc/articles/PMC4981975/.

48. Cardoso F, van't Veer LJ, Bogaerts J, Slaets L, Viale G, Delaloge S, et al. 70-Gene Signature as an Aid to Treatment Decisions in Early-Stage Breast Cancer. N Engl J Med [Internet]. Massachussetts Medical Society; 2016 [cited 2020 Apr 4];375:717-29. https://doi.org/10.1056/NEJMoa1602253.

49. Jatoi I, Anderson WF, Jeong JH, Redmond CK. Breast cancer adjuvant therapy: Time to consider its time-dependent effects [Internet]. J. Clin. Oncol. 2011 [cited 2020 Apr 4]. p. 2301-4. http://www.ncbi.nlm.nih.gov/pubmed/21555693.

50. Davies C, Pan H, Godwin J, Gray R, Arriagada R, Raina V, et al. Long-term effects of continuing adjuvant tamoxifen to 10 years versus stopping at 5 years after diagnosis of oestrogen receptor-positive breast cancer: ATLAS, a randomised trial. Lancet. 2013;381:805-16.

51. Goss PE, Ingle JN, Pritchard KI, Robert NJ, Muss H, Gralow J, et al. Extending Aromatase-Inhibitor Adjuvant Therapy to 10 Years. N Engl J Med [Internet]. Massachussetts Medical Society; 2016 [cited 2020 Apr 4];375:209-19. https://doi.org/10.1056/ NEJMoa1604700.

52. Mamounas EP, Bandos H, Lembersky BC, Jeong JH, Geyer $\mathrm{CE}$, Rastogi $\mathrm{P}$, et al. Use of letrozole after aromatase inhibitorbased therapy in postmenopausal breast cancer (NRG Oncology/ NSABP B-42): a randomised, double-blind, placebo-controlled, phase 3 trial. Lancet Oncol. 2019;20:88-99.

53. Burstein HJ, Lacchetti C, Anderson H, Buchholz TA, Davidson $\mathrm{NE}$, Gelmon KA, et al. Adjuvant endocrine therapy for women with hormone receptor-positive breast cancer: ASCO clinical practice guideline focused update. J Clin Oncol. 2019;37:423-38.

54. Baum M, Buzdar A, Cuzick J, Forbes J, Houghton J, Howell A, et al. Anastrozole Alone or in Combination with Tamoxifen 
versus Tamoxifen Alone for Adjuvant Treatment of Postmenopausal Women with Early-Stage Breast Cancer: Results of the ATAC (Arimidex, Tamoxifen Alone or in Combination) Trial Efficacy and Safety Update Analyses. Cancer [Internet]. John Wiley and Sons Inc.; 2003 [cited 2020 Apr 4];98:1802-10. http:// www.ncbi.nlm.nih.gov/pubmed/14584060.

55. Ethier JL, Desautels D, Templeton A, Shah PS, Amir E. Prognostic role of neutrophil-to-lymphocyte ratio in breast cancer: A systematic review and meta-analysis. Breast Cancer Res [Internet]. BioMed Central Ltd.; 2017 [cited 2021 Apr 5];19. https:// pubmed.ncbi.nlm.nih.gov/28057046/.

56. Aguirre-Ghiso JA. Models, mechanisms and clinical evidence for cancer dormancy [Internet]. Nat. Rev. Cancer. 2007 [cited 2020 Apr 4]. p. 834-46. http://www.ncbi.nlm.nih.gov/pubmed/17957 189.

57. Kim RS, Avivar-Valderas A, Estrada Y, Bragado P, Sosa MS, Aguirre-Ghiso JA, et al. Dormancy signatures and metastasis in estrogen receptor positive and negative breast cancer. PLoS One [Internet]. 2012 [cited 2020 Apr 4];7:e35569. http://www.ncbi. nlm.nih.gov/pubmed/22530051.

58. Sparano JA, Gray RJ, Makower DF, Pritchard KI, Albain KS, Hayes DF, et al. Adjuvant Chemotherapy Guided by a 21-Gene Expression Assay in Breast Cancer. N Engl J Med [Internet]. New England Journal of Medicine (NEJM/MMS); 2018 [cited 2021 Feb 1];379:111-21. https://doi.org/10.1056/nejmoa1804 710.

59. Salgado R, Denkert C, Demaria S, Sirtaine N, Klauschen F, Pruneri G, et al. The evaluation of tumor-infiltrating lymphocytes (TILS) in breast cancer: Recommendations by an International TILS Working Group 2014 [Internet]. Ann. Oncol. Feb, 2015 p. 259-71. http://www.ncbi.nlm.nih.gov/pubmed/25214542.

60. Buisseret L, Garaud S, De Wind A, Van den Eynden G, Boisson A, Solinas C, et al. Tumor-infiltrating lymphocyte composition, organization and PD-1/PD-11 expression are linked in breast cancer. Oncoimmunology [Internet]. Taylor and Francis Inc.; 2017 [cited 2020 Jul 27];6. /pmc/articles/ PMC5283629/?report=abstract.

61. Buisseret L, Garaud S, De Wind A, Van den Eynden G, Boisson A, Solinas C, et al. Tumor-infiltrating lymphocyte composition, organization and PD-1/PD-11 expression are linked in breast cancer. Oncoimmunology [Internet]. Taylor and Francis Inc.; 2017 [cited 2020 Apr 17];6:e1257452. http://www.ncbi.nlm.nih.gov/ pubmed/28197375.

62. Garaud S, Zayakin P, Buisseret L, Rulle U, Silina K, De Wind A, et al. Antigen specificity and clinical significance of IgG and IgA autoantibodies produced in situby tumor-infiltrating b cells in breast cancer. Front Immunol [Internet]. Frontiers Media S.A.; 2018 [cited 2020 Apr 4];9:2660. http://www.ncbi.nlm.nih.gov/ pubmed/30515157.

63. Zhu B, Tse LA, Wang D, Koka H, Zhang T, Abubakar M, et al. Immune gene expression profiling reveals heterogeneity in luminal breast tumors. Breast Cancer Res [Internet]. BioMed Central Ltd.; 2019 [cited 2021 Feb 12];21:147. https://doi.org/10.1186/ s13058-019-1218-9.

64. Shee K, Yang W, Hinds JW, Hampsch RA, Varn FS, Traphagen NA, et al. Therapeutically targeting tumor microenvironmentmediated drug resistance in estrogen receptor-positive breast cancer. J Exp Med. 2018;215:895-910.

65. Criscitiello C, Vingiani A, Maisonneuve P, Viale G, Viale G, Curigliano G. Tumor-infiltrating lymphocytes (TILs) in ER+/ HER 2- breast cancer. Breast Cancer Res Treat [Internet]. Springer; 2020 [cited 2020 Jul 27]; https://pubmed.ncbi.nlm. nih.gov/32621251/.

66. Denkert C, Loibl S, Noske A, Roller M, Müller BM, Komor M, et al. Tumor-associated lymphocytes as an independent predictor of response to neoadjuvant chemotherapy in breast cancer. $\mathrm{J}$
Clin Oncol [Internet]. 2010 [cited 2020 Apr 4];28:105-13. http:// www.ncbi.nlm.nih.gov/pubmed/19917869.

67. Gao Z hua, Li C xin, Liu M, Jiang J yuan. Predictive and prognostic role of tumour-infiltrating lymphocytes in breast cancer patients with different molecular subtypes: a meta-analysis. BMC Cancer [Internet]. BioMed Central Ltd; 2020 [cited $2021 \mathrm{Feb}$ 12];20:1150. https://doi.org/10.1186/s12885-020-07654-y.

68. Waks AG, Stover DG, Guerriero JL, Dillon D, Barry WT, Gjini $\mathrm{E}$, et al. The immune microenvironment in hormone receptorpositive breast cancer before and after preoperative chemotherapy. Clin Cancer Res [Internet]. American Association for Cancer Research Inc.; 2019 [cited 2021 Feb 15];25:4644-55. https://pubmed.ncbi.nlm.nih.gov/31061067/.

69. Spring LM, Fell G, Arfe A, Sharma C, Greenup R, Reynolds KL, et al. Pathologic Complete Response after Neoadjuvant Chemotherapy and Impact on Breast Cancer Recurrence and Survival: A Comprehensive Meta-analysis. Clin Cancer Res [Internet]. American Association for Cancer Research Inc.; 2020 [cited 2021 Feb 12];26:2838-48. /pmc/articles/PMC7299787/.

70. Mao Y, Qu Q, Chen X, Huang O, Wu J, Shen K. The prognostic value of tumor-infiltrating lymphocytes in breast cancer: A systematic review and meta-analysis. PLoS One [Internet]. Public Library of Science; 2016 [cited 2021 Feb 11];11:e0152500. https://doi.org/10.1371/journal.pone.0152500.

71. Mahmoud SMA, Paish EC, Powe DG, Macmillan RD, Grainge MJ, Lee AHS, et al. Tumor-infiltrating CD8+ lymphocytes predict clinical outcome in breast cancer. J Clin Oncol [Internet]. 2011 [cited 2020 Apr 4];29:1949-55. http://www.ncbi.nlm.nih. gov/pubmed/21483002.

72. Josefowicz SZ, Lu L-F, Rudensky AY. Regulatory T cells: mechanisms of differentiation and function. Annu Rev Immunol. 2012;30:531-64.

73. Gobert M, Treilleux I, Bendriss-Vermare N, Bachelot T, Goddard-Leon S, Arfl V, et al. Regulatory T cells recruited through CCL22/CCR4 are selectively activated in lymphoid infiltrates surrounding primary breast tumors and lead to an adverse clinical utcome. Cancer Res [Internet]. American Association for Cancer Research Inc.; 2009 [cited 2020 Apr 4];69:2000-9. http://www. ncbi.nlm.nih.gov/pubmed/19244125.

74. De Kruijf EM, Van Nes JGH, Sajet A, Tummers QRJG, Putter H, Osanto S, et al. The predictive value of HLA class I tumor cell expression and presence of intratumoral tregs for chemotherapy in patients with early breast cancer. Clin Cancer Res [Internet]. 2010 [cited 2020 Apr 4];16:1272-80. http://www.ncbi.nlm.nih. gov/pubmed/20145162.

75. Mahmoud SMA, Paish EC, Powe DG, MacMillan RD, Lee AHS, Ellis IO, et al. An evaluation of the clinical significance of FOXP3+ infiltrating cells in human breast cancer. Breast Cancer Res Treat [Internet]. 2011 [cited 2020 Apr 4];127:99-108. http:// www.ncbi.nlm.nih.gov/pubmed/20556505.

76. Qian F, Qingping Y, Linquan W, xiaojin H, Rongshou W, Shanshan R, et al. High tumor-infiltrating FoxP3+ T cells predict poor survival in estrogen receptor-positive breast cancer: a metaanalysis. Eur J Surg Oncol [Internet]. W.B. Saunders Ltd; 2017 [cited 2020 Apr 4];43:1258-64. http://www.ncbi.nlm.nih.gov/ pubmed/28214052.

77. Liu S, Foulkes WD, Leung S, Gao D, Lau S, Kos Z, et al. Prognostic significance of FOXP3 + tumor-infiltrating lymphocytes in breast cancer depends on estrogen receptor and human epidermal growth factor receptor- 2 expression status and concurrent cytotoxic T-cell infiltration. Breast Cancer Res [Internet]. BioMed Central Ltd.; 2014 [cited 2020 Apr 4];16:432. http://www.ncbi. nlm.nih.gov/pubmed/25193543.

78. Bates GJ, Fox SB, Han C, Leek RD, Garcia JF, Harris AL, et al. Quantification of regulatory T cells enables the identification of high-risk breast cancer patients and those at risk of late relapse. 
J Clin Oncol [Internet]. 2006 [cited 2020 Apr 4];24:5373-80. http://www.ncbi.nlm.nih.gov/pubmed/17135638.

79. Benoist C, Mathis D. Treg cells, life history, and diversity. Cold Spring Harb Perspect Biol [Internet]. Cold Spring Harbor Laboratory Press; 2012 [cited $2020 \mathrm{Apr} 4$ ];4:a007021. http://www. ncbi.nlm.nih.gov/pubmed/22952391.

80. Katoh M, Igarashi M, Fukuda H, Nakagama H, Katoh M. Cancer genetics and genomics of human FOX family genes. Cancer Lett. 2013. p. 198-206.

81. Banham AH, Beasley N, Campo E, Fernandez PL, Fidler C, Gatter K, et al. The FOXP1 winged helix transcription factor is a novel candidate tumor suppressor gene on chromosome $3 \mathrm{p}$. Cancer Res. 2001;61:8820-9.

82. Hu H, Wang B, Borde M, Nardone J, Maika S, Allred L, et al. Foxp1 is an essential transcriptional regulator of B cell development. Nat Immunol [Internet]. 2006 [cited 2020 Apr 4];7:81926. http://www.ncbi.nlm.nih.gov/pubmed/16819554.

83. Shi C, Sakuma M, Mooroka T, Liscoe A, Gao H, Croce KJ, et al. Down-regulation of the forkhead transcription factor Foxp1 is required for monocyte differentiation and macrophage function. Blood [Internet]. 2008 [cited 2020 Apr 4];112:4699-711. http:// www.ncbi.nlm.nih.gov/pubmed/18799727.

84. Shi C, Zhang X, Chen Z, Sulaiman K, Feinberg MW, Ballantyne $\mathrm{CM}$, et al. Integrin engagement regulates monocyte differentiation through the forkhead transcription factor Foxp1. J Clin Invest [Internet]. 2004 [cited 2020 Apr 4];114:408-18. http:// www.ncbi.nlm.nih.gov/pubmed/15286807.

85. Feng X, Ippolito GC, Tian L, Wiehagen K, Oh S, Sambandam A, et al. Foxp1 is an essential transcriptional regulator for the generation of quiescent naive $\mathrm{T}$ cells during thymocyte development. Blood. 2010;115:510-8.

86. Feng X, Wang H, Takata H, Day TJ, Willen J, Hu H. Transcription factor Foxp1 exerts essential cell-intrinsic regulation of the quiescence of naive T cells. Nat Immunol [Internet]. 2011 [cited 2020 Apr 4];12:544-50. http://www.ncbi.nlm.nih.gov/pubmed/ 21532575 .

87. Garaud S, Roufosse F, De Silva P, Gu-Trantien C, Lodewyckx $\mathrm{JN}$, Duvillier H, et al. FOXP1 is a regulator of quiescence in healthy human CD4+ T cells and is constitutively repressed in $\mathrm{T}$ cells from patients with lymphoproliferative disorders. Eur $\mathbf{J}$ Immunol [Internet]. Wiley-VCH Verlag; 2017 [cited 2020 Apr 4];47:168-79. http://www.ncbi.nlm.nih.gov/pubmed/27861791.

88. Shi B, Geng J, Wang Y-H, Wei H, Walters B, Li W, et al. Foxp1 negatively regulates $\mathrm{T}$ follicular helper cell differentiation and germinal center responses by controlling cell migration and CTLA-4. J Immunol. 2018;200:586-94.

89. Stephen TL, Rutkowski MR, Allegrezza MJ, Perales-Puchalt A, Tesone AJ, Svoronos N, et al. Transforming growth factor $\beta$-mediated suppression of antitumor T cells requires Foxp1 transcription factor expression. Immunity [Internet]. Cell Press; 2014 [cited 2020 Apr 4];41:427-39. http://www.ncbi.nlm.nih. gov/pubmed/25238097.

90. Konopacki C, Pritykin Y, Rubtsov Y, Leslie CS, Rudensky AY. Transcription factor Foxp1 regulates Foxp3 chromatin binding and coordinates regulatory $\mathrm{T}$ cell function. Nat Immunol. 2019;20:232-42.

91. Fox SB, Brown P, Han C, Ashe S, Leek RD, Harris AL, et al. Expression of the forkhead transcription factor FOXP1 is associated with estrogen receptor $\alpha$ and improved survival in primary human breast carcinomas. Clin Cancer Res. 2004;10:3521-7.

92. Shigekawa T, Ijichi N, Ikeda K, Horie-Inoue K, Shimizu C, Saji S, et al. FOXP1, an estrogen-inducible transcription factor, modulates cell proliferation in breast cancer cells and 5-year recurrence-free survival of patients with tamoxifen-treated breast cancer. Horm Cancer [Internet]. Horm Cancer; 2011 [cited 2020 Jun 7];2:286-297. https://doi.org/10.1007/s12672-011-0082-6.
93. Halacli SO, Dogan AL. FOXP1 regulation via the PI3K/Akt/ p70S6K signaling pathway in breast cancer cells. Oncol Lett. 2015;9:1482-8.

94. Rayoo M, Yan M, Takano EA, Bates GJ, Brown PJ, Banham $\mathrm{AH}$, et al. Expression of the forkhead box transcription factor FOXP1 is associated with oestrogen receptor alpha, oestrogen receptor beta and improved survival in familial breast cancers. J Clin Pathol. 2009;62:896-902.

95. De Silva P, Garaud S, Solinas C, de Wind A, Van den Eyden $\mathrm{G}$, Jose V, et al. FOXP1 negatively regulates tumor infiltrating lymphocyte migration in human breast cancer. EBioMedicine. Elsevier B.V.; 2019;39:226-38.

96. Linsley PS, Bradshaw J, Greene J, Peach R, Bennett KL, Mittler RS. Intracellular trafficking of CTLA-4 and focal localization towards sites of TCR engagement. Immunity [Internet]. 1996 [cited 2020 Apr 17];4:535-43. http://www.ncbi.nlm.nih.gov/ pubmed/8673700.

97. Probst HC, McCoy K, Okazaki T, Honjo T, Van Den Broek $\mathrm{M}$. Resting dendritic cells induce peripheral CD8+ T cell tolerance through PD-1 and CTLA-4. Nat Immunol [Internet]. 2005;6:280-6 (cited 2020 Apr 17).

98. Olson BM, Jankowska-Gan E, Becker JT, Vignali DAA, Burlingham WJ, McNeel DG. Human prostate tumor antigen-specific CD8 + regulatory T cells are inhibited by CTLA- 4 or IL-35 blockade. J Immunol. 2012;189:5590-601.

99. Boor PPC, Metselaar HJ, de Jonge S, Mancham S, van der Laan LJW, Kwekkeboom J. Human plasmacytoid dendritic cells induce CD8+LAG-3+Foxp3+CTLA-4+ regulatory T cells that suppress allo-reactive memory T cells. Eur J Immunol [Internet]. 2011;41:1663-74 (cited 2020 Apr 17).

100. Demaria S, Kawashima N, Yang AM, Devitt ML, Babb JS, Allison JP, et al. Immune-mediated inhibition of metastases after treatment with local radiation and CTLA-4 blockade in a mouse model of breast cancer. Clin Cancer Res. 2005;11:728-34.

101. Hlavata Z, Solinas C, De Silva P, Porcu M, Saba L, Willard-Gallo $\mathrm{K}$, et al. The abscopal effect in the era of cancer immunotherapy: a spontaneous synergism boosting anti-tumor immunity? Target Oncol [Internet]. 2018;13:113-23. https://doi.org/10.1007/ s11523-018-0556-3 (cited 2020 Apr 4).

102. Mao H, Zhang L, Yang Y, Zuo W, Bi Y, Gao W, et al. New insights of CTLA-4 into Its biological function in breast cancer. Curr Cancer Drug Targets. 2010;10:728-36.

103. Sasidharan Nair V, El Salhat H, Taha RZ, John A, Ali BR, Elkord E. DNA methylation and repressive $\mathrm{H} 3 \mathrm{~K} 9$ and $\mathrm{H} 3 \mathrm{~K} 27$ trimethylation in the promoter regions of PD-1, CTLA-4, TIM-3, LAG3, TIGIT, and PD-L1 genes in human primary breast cancer. Clin Epigenet [Internet]. 2018;10:78 (cited 2020 Apr 17).

104. Kassardjian A, Shintaku PI, Moatamed NA. Expression of immune checkpoint regulators, cytotoxic T lymphocyte antigen 4 (CTLA-4) and programmed death-ligand 1 (PD-L1), in female breast carcinomas. PLoS One [Internet]. 2018;13:e0195958 (cited 2020 Apr 17).

105. Yu H, Yang J, Jiao S, Li Y, Zhang W, Wang J. Cytotoxic T lymphocyte antigen 4 expression in human breast cancer: implications for prognosis. Cancer Immunol Immunother [Internet]. 2015;64:853-60 (cited 2020 Apr 17).

106. Ostapchuk YO, Perfilyeva YV, Kustova EA, Urazalieva NT, Omarbaeva NA, Talaeva SG, et al. Functional heterogeneity of circulating $\mathrm{T}$ regulatory cell subsets in breast cancer patients. Breast Cancer [Internet]. 2018;25:687-97 (cited 2020 Apr 17).

107. Solinas C, Garaud S, De Silva P, Boisson A, Van den Eynden $\mathrm{G}$, de Wind $\mathrm{A}$, et al. Immune checkpoint molecules on tumorinfiltrating lymphocytes and their association with tertiary lymphoid structures in human breast cancer. Front Immunol [Internet]. Frontiers Media S.A.; 2017 [cited 2020 Jul 27];8. https:// pubmed.ncbi.nlm.nih.gov/29163490/. 
108. Solinas C, Aiello M, De Silva P, Gu-Trantien C, Migliori E, Willard-Gallo K. Targeting PD-1 in cancer: biological insights with a focus on breast cancer [Internet]. Crit Rev. Oncol. Hematol. Elsevier Ireland Ltd; 2019 [cited 2020 Apr 17]. p. 35-43. http:// www.ncbi.nlm.nih.gov/pubmed/31357142.

109. Chen J, Jiang CC, Jin L, Zhang XD. Regulation of PD-L1: a novel role of pro-survival signalling in cancer. Ann Oncol. 2016;27(3):409-16.

110. Nishimura H, Nose M, Hiai H, Minato N, Honjo T. Development of lupus-like autoimmune diseases by disruption of the PD-1 gene encoding an ITIM motif-carrying immunoreceptor. Immunity. 1999;11:141-51.

111. Solinas C, Garaud S, De Silva P, Boisson A, Van den Eynden $\mathrm{G}$, de Wind A, et al. Immune checkpoint molecules on tumorinfiltrating lymphocytes and their association with tertiary lymphoid structures in human breast cancer. Front Immunol [Internet]. 2017;8:1412 (cited 2019 Apr 7).

112. Sabatier R, Finetti P, Mamessier E, Adelaide J, Chaffanet M, Ali HR, et al. Prognostic and predictive value of PDL1 expression in breast cancer. Oncotarget. 2015;6:5449-64.

113. Shuai C, Yang X, Pan H, Han W. Estrogen Receptor Downregulates Expression of PD-1/PD-L1 and Infiltration of CD8+ T Cells by Inhibiting IL-17 Signaling Transduction in Breast Cancer. Front Oncol [Internet]. Frontiers Media S.A.; 2020 [cited 2021 Feb 15];10. https://pubmed.ncbi.nlm.nih.gov/33102239/.

114. Li X, Wetherilt CS, Krishnamurti U, Yang J, Ma Y, Styblo TM, et al. Stromal PD-L1 expression is associated with better diseasefree survival in triple-negative breast cancer. Am J Clin Pathol [Internet]. 2016;146:496-502 (cited 2020 Mar 27).

115. Beckers RK, Selinger CI, Vilain R, Madore J, Wilmott JS, Harvey $\mathrm{K}$, et al. Programmed death ligand 1 expression in triplenegative breast cancer is associated with tumour-infiltrating lymphocytes and improved outcome. Histopathology [Internet]. 2016;69:25-34 (cited 2020 Mar 27).

116. Ali HR, Glont S-ES-E, Blows FM, Provenzano E, Dawson S-JS$\mathrm{J}$, Liu B, et al. PD-L1 protein expression in breast cancer is rare, enriched in basal-like tumours and associated with infiltrating lymphocytes. Ann Oncol [Internet]. 2015;26:1488-93. https:// doi.org/10.1093/annonc/mdv192 (cited 2019 Apr 7).

117. Schalper KA, Velcheti V, Carvajal D, Wimberly H, Brown J, Pusztai L, et al. In situ tumor PD-L1 mRNA expression is associated with increased tils and better outcome in breast carcinomas. Clin Cancer Res [Internet]. 2014;20:2773-82 (cited 2020 Mar 27).

118. Sabatier R, Finetti P, Mamessier E, Adelaide J, Chaffanet M, Ali HR, et al. Prognostic and predictive value of PDL1 expression in breast cancer. Oncotarget [Internet]. 2015;6:5449-64 (cited 2019 Apr 7).

119. Uhercik M, Sanders AJ, Owen S, Davies EL, Sharma AK, Jiang WG, et al. Clinical significance of PD1 and PDL1 in human breast cancer. Anticancer Res [Internet]. 2017;37:4249-54 (cited 2020 Mar 27).

120. Wu Z, Zhang L, Peng J, Xu S, Zhou L, Lin Y, et al. Predictive and prognostic value of PDL1 protein expression in breast cancer patients in neoadjuvant setting. Cancer Biol Ther. 2019;20:941-7.

121. Spring L, Fell G, Arfe A, Trippa L, Greenup R, Reynolds K, et al. Abstract GS2-03: Pathological complete response after neoadjuvant chemotherapy and impact on breast cancer recurrence and mortality, stratified by breast cancer subtypes and adjuvant chemotherapy usage: Individual patient-level meta-analyses of over 27,00. Cancer Res. American Association for Cancer Research (AACR); 2019. p. GS2-03-GS2-03.

122. Zerdes I, Sifakis EG, Matikas A, Chrétien S, Tobin NP, Hartman J, et al. Programmed death-ligand 1 gene expression is a prognostic marker in early breast cancer and provides additional prognostic value to 21 -gene and 70-gene signatures in estrogen receptor-positive disease. Mol Oncol [Internet]. 2020;14:951-63 (cited 2021 Feb 15).

123. Strasser A, Jost PJ, Nagata S. The Many Roles of FAS Receptor Signaling in the Immune System. Immunity. NIH Public Access; 2009. p. 180-92.

124. Igney FH, Krammer PH. Tumor counterattack: Fact or fiction? Cancer Immunol Immunother [Internet]. 2005 [cited 2020 Apr 4]. p. 1127-36. http://www.ncbi.nlm.nih.gov/pubmed/15889255.

125. Mansouri A, Ridgway LD, Korapati AL, Zhang Q, Tian L, Wang $\mathrm{Y}$, et al. Sustained activation of JNK/p38 MAPK pathways in response to cisplatin leads to Fas ligand induction and cell death in ovarian carcinoma cells. J Biol Chem. 2003;278:19245-56.

126. Zhu J, Powis De Tenbossche CG, Cané S, Colau D, Van Baren N, Lurquin $\mathrm{C}$, et al. Resistance to cancer immunotherapy mediated by apoptosis of tumor-infiltrating lymphocytes. Nat Commun. 2017;8:1-15.

127. Bebenek M, Duś D, Koźlak J. Prognostic value of the Fas/Fas ligand system in breast cancer. Wspolczesna Onkol. Poznan: Termedia Publishing; 2013. p. 120-2.

128. Mottolese M, Buglioni S, Bracalenti C, Cardarelli MA, Ciabocco L, Giannarelli D, et al. Prognostic relevance of altered Fas (CD95)-system in human breast cancer. Int J Cancer [Internet]. 2000;89:127-32 (cited 2020 Mar 26).

129. Reimer T, Koczan D, Müller H, Friese K, Thiesen HJ, Gerber B. Tumour Fas ligand: Fas ratio greater than 1 is an independent marker of relative resistance to tamoxifen therapy in hormone receptor positive breast cancer. Breast Cancer Res. 2002;4:R9.

130. Botti C, Buglioni S, Benevolo M, Giannarelli D, Papaldo P, Cognetti F, et al. Altered expression of FAS system is related to adverse clinical outcome in stage I-II breast cancer patients treated with adjuvant anthracycline-based chemotherapy. Clin Cancer Res. 2004;10:1360-5.

131. Nanda R, Liu MC, Yau C, Shatsky R, Pusztai L, Wallace A, et al. Effect of pembrolizumab plus neoadjuvant chemotherapy on pathologic complete response in women with early-stage breast cancer: an analysis of the ongoing phase 2 adaptively randomized I-SPY2 trial. JAMA Oncol [Internet]. 2020;6:676-84 (cited 2021 Feb 12).

132. Rugo HS, Delord JP, Im SA, Ott PA, Piha-Paul SA, Bedard PL, et al. Safety and antitumor activity of pembrolizumab in patients with estrogen receptor-positive/human epidermal growth factor receptor 2-negative advanced breast cancer. Clin Cancer Res [Internet]. 2018;24:2804-11 (cited 2021 Feb 12).

133. Tolaney SM, Barroso-Sousa R, Keenan T, Li T, Trippa L, VazLuis I, et al. Effect of eribulin with or without pembrolizumab on progression-free survival for patients with hormone receptorpositive, ERBB2-negative metastatic breast cancer: a randomized clinical trial. JAMA Oncol [Internet]. 2020;6:1598-605 (cited 2021 Feb 12).

134. Rugo HS, Beck JT, Jerusalem G, Wildiers H, Kabos P, Chisamore M, et al. Abstract CT108: A phase 1b study of abemaciclib in combination with pembrolizumab for patients (pts) with hormone receptor positive $(\mathrm{HR}+)$, human epidermal growth factor receptor 2 negative (HER2-) metastatic breast cancer (mBC) (NCT02779751): Preliminary results. Cancer Res [Internet]. American Association for Cancer Research (AACR); 2020 [cited 2021 Feb 12]. p. CT108-CT108. https://www.cancerres.aacrj ournals.org/content/80/16_Supplement/CT108.

135. Dalenc F, Garberis I, Filleron T, Lusque A, Bachelot T, Arnedos $\mathrm{M}$, et al. Durvalumab compared to maintenance chemotherapy in patients with metastatic breast cancer: results from phase II randomized trial SAFIR02-IMMUNO [Internet]. [cited $2021 \mathrm{Feb}$ 12]. https://www.abstractsonline.com/pp8/\#!/7946/presentation/ 2168. 
136. Mattarollo SR, Loi S, Duret H, Ma Y, Zitvogel L, Smyth MJ. Pivotal role of innate and adaptive immunity in anthracycline chemotherapy of established tumors. Cancer Res [Internet]. 2011;71:4809-20 (cited 2020 Mar 30).

137. Goto W, Kashiwagi S, Asano Y, Takada K, Morisaki T, Fujita H, et al. Eribulin promotes antitumor immune responses in patients with locally advanced or metastatic breast cancer. Anticancer Res [Internet]. 2018;38:2929-38 (cited 2020 Mar 30).

138. Schultes B, Hou F, Daley G, Wang L, Smith L, Nicodemus C. Taxanes can enhance immunotherapy of cancer-importance of timing. Cancer Res. 2008;68(9 Supplement):68.

139. Liu Y, Dong Y, Kong L, Shi F, Zhu H, Yu J. Abscopal effect of radiotherapy combined with immune checkpoint inhibitors. J Hematol Oncol. 2018;11(1):104.

140. Slone HB, Peters LJ, Milas L. Effect of host immune capability on radiocurability and subsequent transplantability of a murine fibrosarcoma. J Natl Cancer Inst. 1979;63:1229-35.
141. Stamell EF, Wolchok JD, Gnjatic S, Lee NY, Brownell I. The abscopal effect associated with a systemic anti-melanoma immune response. Int J Radiat Oncol Biol Phys. 2013;85:293-5.

142. Generali D, Bates G, Berruti A, Brizzi MP, Campo L, Bonardi $\mathrm{S}$, et al. Immunomodulation of FOXP3+ regulatory $\mathrm{T}$ cells by the aromatase inhibitor letrozole in breast cancer patients. Clin Cancer Res. 2009;15:1046-51.

143. Page DB, Bear H, Prabhakaran S, Gatti-Mays ME, Thomas A, Cobain E, et al. Two may be better than one: PD-1/PD-L1 blockade combination approaches in metastatic breast cancer. npj Breast Cancer. Nature Publishing Group; 2019.

144. Rugo H, Kabos P, Dickler M, John W, Smith I, Lu Y, et al. Abstract P1-09-01: a phase 1b study of abemaciclib plus pembrolizumab for patients with hormone receptor-positive (HR+), human epidermal growth factor receptor 2-negative (HER2-) metastatic breast cancer (MBC). Cancer Res. American Association for Cancer Research (AACR); 2018. p. P1-09-01-P1-09-01. 